\title{
PASSADOS A CONSTRUIR: SOBRE UM OUTRO mundo, de Gustaw Herling-GrudzińSKI ${ }^{1}$
}

Marcelo Paiva de Souza

[...] na verdade, logo a seguir estanquei, como a recuar dum báratro, ante a visão de coisas espantosas e de fatos mais que nefandos.

Dostoı́́vsKi (Recordações da casa dos mortos)

A rotina letrada latino-americana ainda passa ao largo de Inny świat / Um outro mundo (1953), do escritor polonês Gustaw Herling-Grudziński (1919-2000). Dado o firme consenso crítico vigente em torno do livro, aclamado no país de seu autor e alhures como um dos grandes feitos da literatura do século XX, já se pode antever boa parte dos propósitos que norteiam este artigo. $\mathrm{Na}$ falta do texto mesmo de Herling-Grudziński, devidamente traduzido e editado para o público ledor do Brasil e da América hispânica $^{2}$ - falta temporária, esperemos, a suprir-se o quanto antes -, valerá decerto a pena uma tentativa de estender o perímetro de irradiação da obra até nós, dedicando-lhe uma breve apresentação, seguida de um esboço dos vários questionamentos que, aqui e agora, sua leitura é capaz de suscitar.

Sabe-se, porém, que muito pouco do imponente cânon literário polonês, bem como o de toda a Europa do Leste, chegou por ora a ser publicado e de fato conhecido em nosso meio. E sendo assim, havendo em tal acervo tantos títulos merecedores de atenção, de estudo, de debate, cumpre esclarecer sem meias palavras o porquê do tema escolhido, as razóes pelas quais se decidiu pôr em foco Herling-Grudziński e seu duro relato.

\footnotetext{
${ }^{1}$ Uma versão resumida deste trabalho foi apresentada como conferência no I Encontro Latino-Americano de Estudantes de Letras, evento realizado na UnB, de 06 a 12/02/2011.

${ }^{2}$ Para bem da precisão, é preciso registrar que há edição espanhola da obra (traduzida, ao que tudo indica, a partir da versão inglesa): HERLING, Gustaw. Un mundo aparte; trad. José Manuel López. Madrid: Turpial/Amaranto, 2000. A disponibilidade do livro, no entanto, não parece lhe ter garantido efetiva presença nas letras hispano-americanas.
} 
A narrativa de Um outro mundo presta testemunho acerca dos labirintos do Gulag,, aquele "país extraordinário" que, entre outros, Alieksandr Soljenítsin percorreu, "geograficamente retalhado em um arquipélago, mas psicologicamente amoldado em um continente, país quase invisível, quase impalpável, habitado pela população dos detentos [...]" que as nefastas estruturas do terror comunista vitimaram. ${ }^{4 *}$ As ilhas desse assombroso sistema concentracionário ganharam da burocracia soviética a "denominação errônea e lisonjeira de campos de trabalho forçado", * conforme observa Hannah Arendt, a qual tende antes a chamá-las, em vista da escala, dos móveis e da natureza dos crimes ali perpetrados, de "fábricas de cadáveres" e "poços do esquecimento", * termos igualmente utilizados em As origens do totalitarismo para designar os Lager nazistas, não obstante as diferenças que se verificam entre estes últimos e seus congêneres de extração bolchevique. Como também ocorreu sob o nazismo, houve no entanto sobreviventes, a quem apesar de tudo foi dado não morrer nos campos e assim viver para além da morte em vida no Gulag, sobreviventes entre os quais se acharam aqueles que tampouco esmoreceriam ante a árdua tarefa da denúncia e da documentação da barbárie.

Algo do arquipélago, "infinitamente pouco", * segundo o já citado Soljenítsin, pôs-se desse modo a descoberto. Em tributo aos que testemunharam, bem como a todos cuja voz silenciou sem que lograssem fazê-lo, não devemos dar ouvidos a quanto se conseguiu contar?5 Formulada no presente contexto, é de se crer que

\footnotetext{
${ }^{3} \mathrm{O}$ termo consiste em um acrônimo derivado da designação Glawnoie Uprawleniie Lagierii (Administração Geral dos Campos).

${ }^{4}$ Salvo menção em contrário, a tradução das citações para o português é de minha responsabilidade.

${ }^{5}$ Uma resposta frontalmente negativa à pergunta parece improvável, mas não custa supor certo número de objeçôes visando a justificativa da indiferença ou a simples desconversa. Afinal, a velha União Soviética não se desintegrou? A sombra sinistra da cortina de ferro não se esvaneceu, o Muro de Berlim não veio ao chão? Acaso não somos herdeiros da lasnost, há pouco não nos coube até mesmo assistir a uma onda saudosista, a uma revisitação nostálgica dos tempos do socialismo dito realmente existente (fenômeno que na Alemanha foi batizado de $O s$ talgie)? Para retorquir a tudo isso, basta lembrar o impacto que se seguiu à publicação de Gulag: A History, de Anne Applebaum (New York: Doubleday, 2003) - livro premiado com o Pulitzer em 2004 -, oportunidade em que se patenteou o quão longe a opinião pública ocidental ainda desconhece, ou se recusa a assimilar, a realidade histórica dos campos soviéticos e, por conseguinte, o quão necessário se faz trazer de novo o assunto à ordem do dia. Após haver terminado este artigo, tive acesso a uma publicação polonesa recente, em que se trata do custoso
}

* (SOLŽENICYN, Aleksandr. Arcipelago Gulag: 19181956; trad. Maria Olsùfieva. Milano: Arnaldo Mondadori, 1974: 10.)

* (ARENDT, Hannah. Origens do totalitarismo; $1^{\text {a }}$ reimpressão; trad. Roberto Raposo. São Paulo: Cia das Letras, 1990: 480.)

* (Ibidem: 510.)

* (Op. cit.: 10.) 
* (MORAÑA, Mabel. “Documentalismo y ficción: testimonio y narrativa testimonial hispanoamericana en el siglo veinte". In: PIZARRO, Ana (org.). América latina: palavra, literatura e cultura; vol. 3 - Vanguarda e Modernidade. São Paulo: Fundação Memorial da América Latina; Campinas: Ed. da UNICAMP, 1995: 488.)

*(Idem, ibidem.) a pergunta terá por resposta um resoluto sim. Pois vem de longe nas letras da América Latina, e tomou vigoroso ímpeto na segunda metade do século XX, a tradição a que se têm associado conceitos como literatura documental, testemunho, literatura de teor testemunhal, romance verdade ou romance reportagem, tradição cujas muitas variantes e metamorfoses compartilham algumas características básicas comuns: “[...] o entrecruzamento de narrativa e história, a aliança entre ficção e realidade, a vontade, enfim, de veicular uma denúncia, de dar a conhecer ou manter viva a memória de fatos significativos $[\ldots]^{\prime \prime}$.* $^{*}$

Anota ainda a pesquisadora uruguaia Mabel Moraña que os relatos do testimonialismo são "protagonizados em geral por atores sociais pertencentes a setores subalternos [...]" e costumam, portanto, "mostrar-se contra o statu quo ou solidarizar-se com reivindicaçôes ou lutas populares que põem em questão a 'ordem' de sociedades autoritárias, discriminatórias e excludentes", sentido este em que a "literatura testimonial" propõe-se como "literatura de resistência”.* Convém não perder de vista o arrazoado, já que ele nos adverte para os elementos peculiares à problemática do testemunho no âmbito de nossas literaturas, só até certo ponto coincidente, como se vê, com aquela que é própria das obras relativas às atrocidades dos campos stalinistas e nazistas durante a Segunda Guerra Mundial. ${ }^{6}$

Resguardadas todas as distinções, entretanto, resta um nexo fundamental que, salvo engano, talvez propicie a um texto sobre o Gulag uma recepção atenta e produtiva entre nós. Assim como nas diversas modalidades do testimonio, em obras como Um outro mundo, de Herling-Grudziński, ou os Contos de Kolyma, ${ }^{7}$ do escri-

processo - inconcluso, na opinião do autor - de tomada de consciência do Gulag no mundo ocidental. Cf. TOŁCZYK, Dariusz. Gułag w oczach Zachodu. Warszawa: Prószyński i S-ka, 2009. Acerca do fenômeno do saudosismo pela época da URSS, consulte-se MODRZEJEWSKI, Filip \& SZNAJDERMAN, Monika. (red.) Nostalgia. Eseje o tęsknocie za komunizmem. Wołowiec: Czarne, 2002. Acerca da Ostalgie, veja-se SARYUSZ-WOLSKA, Magdalena. Doświadczenie (n)ostalgii. In NYCZ, Ryszard \& ZEIDLER-JANISZEWSKA, Anna. (red.). Nowoczesność jako doświadczenie. Kraków: Universitas, 2002.

${ }^{6}$ Acerca das particularidades das noçôes de Zeugnis e de testimonio no domínio dos estudos literários contemporâneos, consulte-se SELIGMANN-SILVA, Márcio. "Literatura, testemunho e tragédia: pensando algumas diferenças". In: $O$ local da diferença. Ensaios sobre memória, arte, literatura e tradução. São Paulo: Ed. 34, 2005. (Na mesma obra, veja-se também o estudo "Literatura e trauma: um novo paradigma”.)

${ }^{7} \mathrm{O}$ livro não está traduzido para o português. A versão inglesa é de fácil con- 
tor russo Varlam Chalamov, trata-se de rasgar o véu de um silêncio espúrio, de acusar o pesadelo e a ignomínia da violência; trata-se, em última instância, de fazer frente à questão do poder.

Há especificidades a levar em conta, insista-se, e delas decorre a bem dizer o ponto decisivo para essas ponderações. Em uma acerba ironia histórica, a situação nada invejável da Polônia após a eclosão da II Guerra, acuada entre as manobras hostis paralelas de Hitler e de Stalin, acabou por facultar à literatura polonesa condiçóes especialmente vantajosas para o exame da ação dos dois regimes do século XX em que o poder terá talvez assumido sua face mais bestial.

Abordamos aqui um assunto espinhoso, cujo vulto e complexidade ultrapassam em muito os limites da competência do estudioso de letras. Conquanto uma pensadora da importância de Hannah Arendt haja sustentado a tese da existência de duas, "apenas duas formas autênticas de domínio totalitário: a ditadura do nacional-socialismo, a partir de 1938, e a ditadura bolchevista, a partir de 1930 [...]",*8 em data recente, na edição revista de God's Playground: A History of Poland, o historiador Norman Davies assevera (em tom de cabal reprovação, aliás) que "as ideias apresentadas pela teoria do totalitarismo, a qual demonstrou que o comunismo e o fascismo são tipos similares do mesmo fenômeno político, não ganharam apoio universal." ${ }^{* 9}$ Recorde-se também, a propósito, Le livre noir du communisme, editado em Paris em 1997, que se por um lado teve o mérito de reunir e organizar uma formidável pletora de dados, quiçá nunca antes expostos com tamanha contundência, por outro fez acompanhar-se de ferozes polêmicas, à vista das quais força é reconhecer a procedência de parte das investidas contra a obra.*

Desnecessário observar que, em seus aspectos cruciais, a difícil controvérsia em torno do balanço histórico da Revolução de Outubro e de seus desdobramentos requer o instrumental e o dis-

sulta: SHALAMOV, Varlam. The Kolyma Tales; trad. John Glad. London: Penguin, 1994. A primeira edição integral do original russo veio a lume em Londres, em 1978.

${ }^{8}$ A autora concluiu As origens do totalitarismo, recorde-se, em 1949; a primeira edição da obra foi dada à estampa em 1951.

${ }^{9}$ A respeito das relaçôes entre comunismo e fascismo, entendidos como duas vertentes do fenômeno totalitário, consulte-se o instrutivo arrazoado de Tzvetan Todorov, em seu Mémoire du mal, tentation du bien. Enquête sur le siècle. Paris: Robert Laffont, 2000 (em especial os cap. 1, "Le mal du siècle", e 2, "La comparaison").
* (ARENDT, H. Op. cit.: 469.)

* (DAVIES, Norman. God's Playground: A History of Poland; vol. 2; edição revisada. New York: Columbia University Press, 2005: 476.)

* (Cf. COURTOIS, Stéphane WERTH, Nicolas, PANNÉ, Jean-Louis, PACZKOWSKI, Andrzej, BARTOSEK, Karel et MARGOLIN, Jean-Louis. Le livre noir du communisme. Crimes, terreur, répression. Paris: Robert Laffont, 1997.) 
* (BŁOŃSKI, Jan. "Borowski i Herling. Paralela". In: NYCZ, Ryszard \& JARZĘBSKI, Jerzy (red.). Lektury polonistyczne. Kraków: Universitas, 1997: 5.)

* (Cf. BOROWSKI, Tadeusz. Pożegnanie z Marią $i$ inne opowiadania. Wrocław: Wydawnictwo Siedmioróg, 2001.) cernimento da pesquisa especializada. De nossa parte, é o caso tãosó de assinalar, com o grande crítico literário polonês Jan Błoński, que, ante os horrores praticados pelos nazistas e pelos comunistas, as letras na Polônia "reagir[am] com uma simetria digna de nota": as obras dedicadas aos sofrimentos infligidos por um e outro algoz repartem-se de maneira equivalente.* $\mathrm{E}$ - sobretudo - esses textos dialogam entre si, beneficiam-se artisticamente uns dos outros, em virtude da possibilidade de cotejo e elucidação recíproca de seus objetos, bem como do circuito de trocas e disputas efetuadas no plano de seus procedimentos de linguagem. A esse respeito, Um outro mundo é exemplar, visto que consiste numa espécie de resposta polêmica às narrativas de Tadeusz Borowski (1922-1951) sobre Auschwitz, ao niilismo que, segundo Herling-Grudziński, teria contagiado irrevogavelmente a visão de mundo do criador do Vorarbeiter Tadek.*10

Tornamos assim ao livro que nos interessa apresentar e discutir nesta ocasião. Deixando de lado por ora o problema crítico capital constituído pelas relações entre os contos de Borowski e Um outro mundo, passemos em revista as circunstâncias das quais este último se originou. Reduzida a um mero esquema factográfico, a obra de Gustaw Herling-Grudziński registra o período de quase dois anos transcorridos desde a prisão do autor pela NKVD ${ }^{11}$ em março de 1940, em fuga da cidade de Grodno ${ }^{12}$ rumo à Lituânia, até sua libertação, em janeiro de 1942, do campo de trabalho de Iertsévo, nas proximidades de Arkhangielsk, e o intervalo de pouco mais de dois meses passados em trânsito dali até Lugovoie, no Cazaquistão, onde Herling se junta às tropas da $10^{\mathrm{a}} \mathrm{Divi}$ são de Infantaria polonesa, para então seguir com elas, atravessando o mar Cáspio, fronteira persa adentro. A esse espaço de tempo, que abrange a maior parte do que é narrado no texto, soma-se outrossim o breve encontro do escritor, já em junho de 1945, em Roma, com um antigo companheiro de cela da prisão de Vitebsk,

\footnotetext{
${ }^{10}$ A $1^{\text {a }}$ edição do volume de contos $A$ despedida de Maria é de 1947. A tradução inglesa é de fácil acesso: This Way for the Gas, Ladies and Gentlemen; sel. and transl. Barbara Vedders. London: Penguin, 1992.

${ }^{11}$ Naródnii Komissariat Vnutrennikh Diel (Comissariado do Povo para Assuntos Internos) - designação da polícia política de Stalin.

${ }^{12}$ Hoje Hrodna, na Bielorrússia. Mais à frente, onde lê sobre as fronteiras persas, tenha-se em mente a querela em torno do nome legado pelos gregos e a alternativa Irã.
} 
cena cujo relato serve de epílogo ao livro, arrematando-lhe a tersa, compacta composição.

A $1^{\circ}$ de setembro de 1939, recordemos, a Alemanha de Hitler iniciara sua sorrateira ofensiva contra a Polônia. Desde 1937, Herling-Grudziński era estudante da polonística da Universidade de Varsóvia e, como não foi de imediato recrutado para combate, um pouco mais tarde, em meados de outubro, acabou participando da criação da Ação Popular Polonesa pela Independência (Polska Ludowa Akcja Niepodlegtościowa - PLAN), pequeno grupo conspiratório decidido a colaborar com o movimento de resistência. Entretanto, em face do avanço esmagador da soldadesca alemã a oeste e da ocupação do leste do país pelo Exército Vermelho, minguavam drasticamente as possibilidades de reação. Quando o autor foi aprisionado pela polícia política de Stalin, tentava ele alcançar território lituano, para de lá evadir-se para alguma nação ocidental em que pudesse manter ativo seu engajamento em defesa da Polônia. Selava-se assim o seu destino: declarando durante o inquérito a intenção de cruzar a fronteira da Lituânia a fim de combater os alemães (aliados dos soviéticos, desde agosto de 1939, por conta do pacto de Ribbentrop-Molotov ${ }^{13}$ ), Herling-Grudziński será condenado a cinco anos de encarceramento no Gulag por tencionar combater - a União Soviética! Em Um outro mundo reproduz-se o severo protocolo dos trabalhos da justiça stalinista:

Qual é afinal o teor da peça de acusação? - "[O réu] Tencionava cruzar a fronteira soviético-lituana para lutar contra a União Soviética." Não é possível trocar as palavras "contra a União Soviética" pelas palavras "contra a Alemanha"? Um golpe de mão aberta com toda a força de pronto me desiludiu. - "Dá no mesmo" - consoloume o juiz de inquérito, enquanto eu assinava o documento a mim estendido.*

Em seguida à prisão e à exemplar apuração de seus delitos (?!), Herling fica detido alguns meses em um presídio em Vitebsk, donde mais tarde é transportado, passando pelas cidades de Leningrado ${ }^{14}$ e Vologda, para o campo de trabalho em que deveria cumprir seus cinco anos de pena, em Iertsévo. Todavia, as figuras no tabuleiro do conflito mudam de posição. Em resultado do ataque de Hitler à URSS, em meados de 1941 as autoridades do governo polonês no exílio reatam relaçôes diplomáticas com os russos, o que levará

\footnotetext{
${ }^{13}$ Sobre o assunto, confira-se DAVIES, N. Op. cit.: 320-321.

${ }^{14}$ Hoje (de novo) São Petersburgo.
}

* (HERLING-GRUDZIŃSKI, Gustaw. Inny świat. Kraków: Wydawnictwo Literackie, 2010: 40.) 
* (BOLECKI, Włodzimierz. Inny świat Gustawa Herlinga-Grudzińskiego. Kraków: Universitas, 2007: 66.) à assinatura de um pacto bilateral garantindo anistia a todos os cidadãos da Polônia reclusos no Gulag e permitindo ademais a arregimentação em solo soviético de tropas polonesas constituídas de ex-prisioneiros dos campos. ${ }^{15}$ Teoricamente, Herling-Grudziński estava entre os beneficiários dessas medidas. Mas só a muito custo pôde ser contemplado por elas. Ainda detido em Iertsévo meses após a mencionada anistia, o autor resolve valer-se de um recurso extremo. No fim de novembro de 1941, com um punhado de companheiros poloneses, entra em greve de fome reclamando sua liberdade. Os oito dias sem alimento que se sucederam por pouco não trazem um desfecho diverso do intencionado. Contudo, a aposta valeu o risco. Na noite de 19/01/1942, Herling recebe o comunicado oficial sobre sua libertação. Na manhã do dia seguinte, ficarão para trás os portôes do Gulag.

Conforme já se anotou anteriormente, a jornada do escritor pela "terra inumana" ${ }^{16}$ em que degenerou a utopia comunista duraria mais algum tempo. E, uma vez integrado às divisões sob a liderança do general Władysław Anders, Herling-Grudziński segue viagem da Pérsia para o Iraque e, de lá, passando pela Palestina e o Egito, chega à Itália, onde fica internado cerca de três meses em um hospital militar britânico reconvalescendo de uma febre tifoide, antes de reassumir suas funções no exército polonês (em maio de 1944, por exemplo, ele tomará parte na batalha de Monte Cassino). Rastrear em pormenor a biografia de Herling a partir desse ponto é tarefa de que devemos abrir mão, mas convém ter em conta o certeiro juízo de Włodzimierz Bolecki, um dos maiores conhecedores da obra do autor de Um outro mundo: "Como escritor e como homem, [H-G] viveu [todo o restante de sua vida] à enorme sombra do tagier." ${ }^{* 17}$

Comentando a fase final da produção literária grudzińskiana, Bolecki argumenta que, cinquenta anos depois de declarada a paz, "a experiência fundamental para Herling eram ainda os acontecimentos de 1939-1945”, não obstante as diversas temáticas que fre-

\footnotetext{
${ }^{15}$ Sobre o assunto, leia-se mais em DAVIES, N. Op. cit.: 361-364.

${ }^{16}$ Aludo neste passo ao importante livro de Józef Czapski (1896-1993), Na nieludzkiej ziemi, outro título representativo entre os relatos de poloneses que prestam testemunho acerca dos campos da URSS sob Stalin. A primeira edição da obra é de 1949.

${ }^{17}$ Os fragmentos citados no parágrafo seguinte provêm da mesma página, na mesma fonte. Para as informações biográficas, também me valho - essencialmente - do livro de Bolecki.
} 
quentou, sem qualquer relação direta com os incidentes do conflito. "Herling era de opinião", continua o aludido estudioso, "que o que se passou nos campos - nazistas ou bolcheviques - imprimiu um estigma sombrio na história da humanidade. Sublinhou repetidas vezes que essa foi uma experiência que não se podia esquecer." Daí decorreu o fato de que o conjunto de seus escritos haja sido uma incessante meditação acerca das ideologias e do potencial de violência a elas intrínseco; daí "derivou seu vigoroso protesto contra todas as formas de menoscabo ou de apequenamento das consequências da II Guerra Mundial e dos efeitos de ambos os totalitarismos."

Para Herling, Ialta e Potsdam, o cessar-fogo e o começo da Guerra Fria significaram antes de mais nada a inevitabilidade do exílio. Entregue doravante aos arbítrios da política de Moscou, a Polônia deixava de representar uma opção para o autor, o qual, ainda prestando serviço ao exército polonês na Itália, desiste em 1945 do retorno a seu país (em que só se encontrará de novo mais de quarenta anos depois). ${ }^{18}$ Mas, assim como a guerra fez de Herling um exilado, foi também ela - e em especial a travessia pelo Gulag - o fator determinante nos anos de aprendizagem do escritor. A esse respeito merece transcrição um trecho revelador do discurso por ele proferido durante a cerimônia em que recebeu o doutorado honoris causa da Universidade de Lublin, em 1997:

Pergunto-me se nos catres dos presídios e dos campos ou no decurso do assim chamado "trabalho correcional", o ispravitiélni trud, [...] me ocorriam lampejos de pensamento sobre minhas ambiçôes literárias. Não é improvável, visto que mesmo nos momentos mais difíceis de mortal aflição física eu envidava um obstinado esforço - bem me lembro - para manter em estado de permanente tensão minhas faculdades de observação, voltadas tanto para o ambiente à minha volta quanto para o meu próprio âmago. $\mathrm{O}$ que seria prova de que inconscientemente eu me portava como um escritor "juntando material" (se me for lícito o emprego dessa expressão surrada) para uma descrição futura, caso o destino consentisse em

\footnotetext{
${ }^{18}$ Da Itália, Herling emigra para Londres, onde fixa residência de 1947 a 1952, ano em que se muda para Munique. Após pouco mais de dois anos na então Alemanha ocidental, o escritor regressa à Itália, onde finalmente se estabelece, em 1955, na cidade de Nápoles, na qual viverá o resto de seus dias. Durante todo o período de existência da República Popular da Polônia, o nome de Gustaw Herling-Grudziński esteve no index dos inimigos do regime, só vindo a ser dele excluído em 1989. Dois anos depois, enfim Herling vê de novo sua terra natal, sendo agraciado na ocasião com o título de doutor honoris causa da Universidade de Poznań.
} 
* (HERLING-GRUDZIŃSKI, Gustaw. "Być. I pisać". In: Wyjścia z milczenia. Warszawa: Czytelnik, 1998: 473.)

* (Idem. "Literatura wolna i upaństwowiona". Ibidem: 246-247.)

* (BOLECKI, W. Op. cit.: 72.) minha salvação. Estava portanto latente em mim em uma forma um tanto rudimentar o instinto da escrita, já distante porém dos meus interesses no pré-guerra. Em suma, em certo estrato profundo eu amadurecia lentamente para a criação literária, abandonando antigos projetos e propósitos.*

Enfatizemos a parte final da citação: o instinto da escrita possuía feição tosca e incipiente, mas já se mostrava alheio às preocupaçôes nutridas pelo autor antes do cataclismo da guerra; os antigos projetos e propósitos, imaturos, caducavam e cediam lugar àqueles que definiriam propriamente falando o perfil de Gustaw Herling-Grudziński como artista da palavra. ${ }^{19} \mathrm{O}$ desafio que então se impunha, com inarredável urgência, era de monta: tratava-se de brandir a pena contra o Leviatã da máquina estatal comunista, a começar pelo desmascaramento da infâmia dos campos soviéticos, invocando em tal empreitada "as melhores tradiçôes da literatura" e não esquecendo nunca que,

[...] a cada fração de segundo na qual [se lança] no branco da folha de papel uma única palavra, dão testemunho de sua veracidade, com a própria vida, centenas de sombras humanas sucumbindo inteiramente exauridas nas brancas planícies da Sibéria e de Kolyma. Onde encontrará um escritor deveras digno desse nome objetivo mais simples e mais humano para sua criação em nossos tempos de desdém?*

Nessa ordem de ideias, não parece equivocado afirmar que o livro de estreia de Herling - Żywi i umarli. Szkice literackie / Vivos e mortos. Ensaios literários -, dado à estampa em Roma em 1945, bem como quase todos os artigos e resenhas publicados pelo autor desde sua saída do tagier de Iertsévo foram uma espécie de preparação, segundo sustenta o suprarreferido Włodzimierz Bolecki, ${ }^{*}$ para o enfrentamento dos problemas artísticos e intelectuais que mais tarde se cristalizaram em Um outro mundo. Pudemos já nos convencer de que o imperativo moral, o firme sentido ético a orientar a criação literária grudzińskiana, tinha-se definido com perfeita clareza ao longo da II Guerra. Em meados de 1950, entretanto, ao pôr termo à narrativa em que evocou suas memórias do Gulag, ${ }^{20}$

\footnotetext{
${ }^{19}$ Dos onze volumes de sua obra reunida (publicada entre 1994 e 2000, aos cuidados de Zdzisław Kudelski, pela editora Czytelnik, de Varsóvia), gozam de especial apreço os vários volumes do diário do escritor, seus contos e sua ensaística.

${ }^{20} \mathrm{O}$ primeiro fragmento do livro aparece, em forma ainda não definitiva, em 1947, e o grosso do trabalho de elaboração do texto vai estender-se de julho de 1949 a julho de 1950. À época, recorde-se, o autor tinha emigrado para a Ingla-
} 
o escritor polonês havia atinado ademais com a resposta a outra questão: que forma dar ao relato, como narrar, não depois, mas a rigor em face de Kolyma, das ilhas Soloviétski e da vasta indústria dos campos soviéticos e de suas mortíferas operaçôes?

Uma indicação valiosa para elucidar o ponto é fornecida pelo subtítulo da obra: Inny świat. Zapiski sowieckie. O substantivo zapisek equivale em português a "registro", "notação", "nota”, "apontamento", termos que de saída fazem supor, em sua despretensão e generalidade, a recusa do enquadramento estrito de um gênero literário em particular. Com efeito, cognominando sua narrativa de “apontamentos soviéticos", Herling dá azo a que o leitor a aborde por múltiplas vias - como autobiografia, memórias, reportagem, ensaio, tratado, romance -, cada qual delas apta a franquear acesso a uma (ou algumas) das dimensóes do texto, a este ou aquele arranjo dos elementos prismaticamente dispostos em sua trama. Há todavia um eixo fixo, um norte cuja presença se patenteia de modo unívoco em Um outro mundo, a saber, o indivíduo Gustaw Herling-Grudziński, que descarta a prerrogativa autoral de emprego dos recursos da ficção para forjar um narrador e opta ao invés disso por incumbir-se a si mesmo dos deveres deste último. Quem narra, portanto, é Herling-Grudziński, sobrevivente polonês do Gulag, ex-detento do campo de Iertsévo. O que tem implicações muito significativas, a mais óbvia das quais consistindo no fato de que a identidade civil do escritor fica assim obrigada a responder pela verdade do relato, por um lado, e, por outro, a arcar diretamente com o peso de um julgamento pessoal dos fatos relatados.

Vislumbramos aqui o que parece configurar o núcleo mesmo da poética de Inny świat: dizer a verdade sobre o Gulag e julgá-lo. Que não se cometa porém o engano de crer evidentes ou banais o teor de um e de outro postulado e, mais ainda, a delicada imbricação de um no outro na urdidura formal do testemunho grudzińskiano. Como já verificamos, Herling atribuía um papel de primeiro plano à disciplina da observação. Mas o trato tão es-

terra, o que não passará sem consequências no que tange ao itinerário editorial da obra. Concluída a redação de cinco de seus capítulos, eles são traduzidos diretamente do manuscrito para o inglês e submetidos, ato contínuo, a um editor londrino. A impressão que causam é de tal ordem que Herling recebe um adiantamento pela obra, que acaba sendo lançada primeiro em sua versão inglesa, pela Heinemann, em 1951 (com tradução de Andrzej Ciołkosz, sob o pseudônimo Joseph Marek). Segue-se então, também em Londres, em 1953, a publicação do original polonês (pela editora Gryf). 
* (HERLING-GRUDZIŃSKI, G. "Proza czasu wojny". In: Wyjścia z milczenia: 121 122.) crupuloso quanto paciente das rugosidades e reentrâncias do real, do seu claro-escuro, das suas estridências e silêncios, característica sem dúvida notável em Um outro mundo, não se deve confundir com acatamento inerte - e muito menos com voluntária retomada - dos ditames artísticos do realismo e do naturalismo do Oitocentos. Pois a substância documental e a motivação ética da obra não eximem seu autor do sempre incerto confronto com as incógnitas da pesquisa de linguagem. Ao contrário, requerem dele redobrada vigilância crítica diante dos procedimentos postos a sua disposição no repertório dos estilos de época passados e presentes. Nos termos da incisiva censura que Herling dirigiu em 1947 à literatura polonesa dedicada à II Guerra, trata-se de resistir à rotineira, enganosa segurança das convenções já estabelecidas, em prol da busca "de um outro olhar e de outros instrumentos" para o fazer literário, na falta dos quais "a areia das novas experiências desliza por entre os [...] dedos" rígidos do escritor.*

A fim de que façamos ideia mais concreta da obra sob escrutínio, convém em seguida proceder a algumas incisões analíticas no texto, por meio das quais se explicitem aspectos relevantes do leque de soluções encontradas pelo autor e de seus respectivos resultados criativos. Parcela não desprezível da força da narrativa grudzińskiana depende das virtudes combinadas da perspicácia, da minúcia e da concisão. No passo reproduzido abaixo, que compreende quase na íntegra o primeiro parágrafo do primeiro capítulo da Parte I do livro, o estilo de Herling-Grudziński apresenta suas armas:

O verão em Vitebsk ia chegando ao fim. À tarde o sol queimava ainda por um instante o chão do pátio do presídio e encerrava seu curso atrás da parede rubra do bloco vizinho. Vinham do pátio o som de passos de prisioneiros, medindo ritmadamente o caminho até o banho, e palavras de comando em russo, mescladas ao ruído de chaves. O guarda no corredor cantarolava, a cada tantos minutos dobrava seu jornal e, sem se apressar em demasia, aproximava-se da janelinha na porta. Duzentos pares de olhos despegavam-se do teto como a um sinal e convergiam para a pequena lente do judas. Debaixo da viseira de oleado do quepe um olho enorme observavanos e após abarcar a cela em um movimento pendular desaparecia sob a folha metálica abaixada.*

Repare-se no movimento certeiro e ágil do foco de atenção do narrador, que precisa apenas de umas poucas linhas para fixar a paisagem de fim de verão e fim de tarde em que tem início o relato e a opressiva partitura de sua música de fundo: a grave percus- 
são da marcha do contingente de reclusos, o russo hostil das ordens que lhes são vociferadas e o intermitente tinir das chaves. A displicência do guarda passando sem pressa pelo corredor contrasta - muito sugestivamente - com a nervosa expectativa dos "duzentos pares de olhos" no interior da cela, para cujo recinto aponta, na moldura quase expressionista do visor na porta (não sem motivo batizado de judasz em polonês), um globo ocular ciclópico em mecânica perquirição.

A limpidez vernacular da linguagem, o desembaraço da sintaxe e a energia do vocabulário trazem à memória do leitor brasileiro o gume da prosa de um Graciliano Ramos, que em suas Memórias do cárcere, aliás, dá promissor ensejo a um estudo comparativo pormenorizado com a obra grudzińskiana aqui em exame. Perceba-se, outrossim, como a frase enxuta do escritor polonês tem o condão de desdobrar-se em metáfora: o dia e o verão que se extinguem, deixando atrás de si a estampa rubra na parede vizinha ao pátio do presídio, evocam uma atmosfera de modorra e difuso agouro. O olho enorme em vigilante vaivém pendular na abertura do judas destaca-se por um momento de qualquer compleição humana, para adquirir simbolicamente o estatuto descarnado de um princípio, para reter no hialino flagrante da imagem a lógica perversa da "civilização carcerária" edificada sob a liderança política bolchevique. ${ }^{21}$

Há um outro detalhe importante a salientar no fragmento em que nos detivemos. A vigilância da máquina prisional aciona em sua esteira a engrenagem reversa da vigilância dos encarcerados. Conquanto reduzido o alcance desta última, a reciprocidade do processo fica clara na pronta convergência da mirada dos presos na direção do olho que os tem em mira. A atitude alerta que aí se demonstra permite talvez cogitar de novos sentidos metafóricos, concernentes agora ao próprio modus operandi do testemunho de Herling-Grudziński. Pois, como divide com os demais condenados o exíguo espaço do confinamento, é dentro desses limites que o narrador tem de mover-se, procedendo metodicamente à revelia dos entraves que cerceiam e turvam seu campo de visão.

\footnotetext{
${ }^{21}$ A fórmula tiuriemnaia tsivilizatsia foi cunhada por Nadiejda Mandelstam em suas Memórias (Grudziński a emprega em seu Dziennik pisany noca / Diário escrito à noite e Włodzimierz Bolecki também a cita; deste último, veja-se a página 87 da obra citada).
} 
* (HERLING-GRUDZIŃSKI, G. Inny świat: 46.)

* (Ibidem: 46-47.)
O trecho citado a seguir, também proveniente do primeiro capítulo da obra, oferece uma vívida descrição dos estratagemas cujo concurso confere corpo e alento a Um outro mundo. Informado dos cálculos de antigos prisioneiros acerca do total de reclusos no presídio de Leningrado (cerca de 40.000 pessoas), Herling julga-lhes verossímeis as estimativas, observando que "eram baseadas principalmente num penoso cotejo e confronto de fatos, indícios e relatos clandestinos." ${ }^{*} \mathrm{E}$ acrescenta:

Um dos fenômenos mais assombrosos e fascinantes na parca vida mental das "casas dos mortos" é a percuciência formidavelmente aguçada da observação de cada detento experimentado. Não havia cela em que não encontrasse ao menos um estatístico e pesquisador da vida prisional, mergulhado dia e noite na reconstrução do quadro da realidade a circundá-lo a partir de um miúdo mosaico de alusóes, estórias, fragmentos de conversa ouvida no corredor, retalhos de jornal encontrado na latrina, de resoluçóes administrativas, do movimento dos veículos no pátio, do som dos passos aproximandose e afastando-se do portão. Em Leningrado, deparei pela primeira vez com hipóteses acerca do número de encarcerados, deportados e escravos brancos na União Soviética. Nas discussōes na prisão a cifra oscilava entre 18 e 25 milhões de pessoas. ${ }^{* 22}$

Não terá passado despercebido o viés metanarrativo do comentário sobre os estatísticos e pesquisadores da existência prisional, figuras de carne e osso, por certo, com quem o escritor polonês pôde travar conhecimento, mas, a par disso, precisa figuração do próprio labor testemunhal grudzińskiano impressa em um refolho especular de seu relato. Atente-se, ademais, na sintomática menção aos dotes de escuta do narrador, que toma nota do que os detentos de Leningrado têm a informar e reconta por sua vez o que lhe foi contado. Novamente, o texto reporta um acontecimento na trajetória do autor e de um mesmo golpe torna manifesto o artesanato de sua confecção, que entretece, em torno do aziago destino comum do Gulag, um espesso fio autobiográfico e os fios do enredo ora mais, ora menos esgarçado de muitas vidas alheias e suas respectivas peripécias. ${ }^{23}$

\footnotetext{
${ }^{22}$ A expressão entre aspas alude ao romance dostoievskiano Recordações da casa dos mortos (1861). As cifras oferecidas por Herling-Grudziński podem ser cruzadas com o cauteloso cômputo final levado a cabo em Gulag: A History, por Anne Applebaum. Veja-se, na op. cit. (cf. nota no 5), o texto do “Appendix: How Many?", p. 515-522, em que se fala de um total de aproximadamente 28.700 .000 presos.

${ }^{23}$ Em "Podalsze od russkoj ziemli...", ensaio magistral dedicado a Um outro mundo, Henryk Siewierski (Spotkanie narodów. Paryż: Instytut Literacki, 1984) vis-
} 
O desígnio de verdade da narração de Herling-Grudziński, portanto - estamos afinal em condições de atestá-lo -, não pressupõe um absoluto de onisciência e objetividade, não aspira a um patamar de certezas dogmáticas; baseia-se, sim, em uma arte sutil e custosa de rastreamento de indícios, em uma tateante combinatória de inferências e subentendidos, de relances e rumores, de aparas de histórias e aturada reflexão. Essa matéria heteróclita e fugidia talvez desperte dúvida. Não seria ela fundamento demasiado tênue para afiançar o êxito do projeto do autor? O oposto disso, de fato, por uma razão que importa frisar: adotando uma perspectiva muito francamente humana, um ponto de vista oblíquo, restrito e lacunar, o relato descortina com dramatismo tanto maior, à luz gritante do contraste, o maciço totalitário dos campos soviéticos e sua radical desumanidade. Se por um lado, contudo, Herling resigna-se a sua plena e falível humanidade como narrador, em detrimento dos (im)possíveis ofertados pela ficção, nunca dispensa, por outro, o privilégio de uma convicta exterioridade do olhar. Para o escritor, muito exatamente falando, o campo é um outro mundo, ${ }^{24}$ com usos e costumes distintos, com habitantes peculiares, sob o governo de leis próprias. Embora arrastado como milhôes de outros para os recessos do Gulag, Herling-Grudziński porfia para manter fora dele a consciência, resguardada dessa maneira a uma distância viável para discernir e julgar.

Note-se a propósito que é da falta de um tal distanciamento que o autor de Inny świat se ressente nos contos de Tadeusz Borowski sobre Oświęcim. Na medida em que elimina um nítido comentário autoral acerca dos eventos que relaciona, confiando às

lumbra no relato grudzińskiano sobre a trajetória de seus companheiros de viagem do Gulag, "esses galés do século XX" (p. 12), a metáfora de um possível êxodo para além do exílio a que foram condenados pela história.

${ }^{24} \mathrm{O}$ título da narrativa grudzińskiana provém de um trecho logo no início do cap. I das Recordaçôes da casa dos mortos. Lembre-se que o romance de Dostoiévski é introduzido por um narrador anônimo, em cujo poder vão parar os papéis e anotaçôes de um liberto dos presídios da Sibéria. Este primeiro narrador sai então de cena, passando a palavra a Alieksandr Piétrovitch Goriantchikov e seu relato sobre a prisão siberiana a que foi condenado: “[...] um mundo bem outro, regido por estatutos, disciplinas, horários específicos; uma casa para cadáveres vivos; uma vida à margem; e homens de vivência muito outra. É este desvão tão diferente da vida que ora me proponho descrever, tal como é." (Cf. Dostoiévski, F. M. Op. cit., p. 21.) Este fragmento serve de epígrafe a Um outro mundo, cujas relaçôes intertextuais com a narrativa dostoievskiana, como se vê, são estreitas e fascinantes. Włodzimierz Bolecki tece em torno delas interessantes considerações (ver op. cit.:173-180 et passim). 
* (HERLING-GRUDZINSSKI, apud BOLECKI, op. cit.: 214 e 223, respectivamente.)

* (Idem, ibidem: 213.) criaturas de sua lavra literária a tarefa de exibir com cinismo e crueza máximos a devastação moral reinante por trás do arame farpado do Lager, Borowski deixa intocado, no entender de seu confrade, o áspero problema da crise de valores de seu tempo. Vítimas e algozes na ficção borowskiana identificam-se no mesmo "desprezo pela fraqueza", no mesmo "culto da astúcia”, o que tanto pode evidenciar a impiedosa agudez de vistas do escritor, como autoriza a temer que ele simplesmente não veja distinção entre o "sistema de crueldade organizada" dos campos e o restante do mundo para lá de seus portões. ${ }^{* 25}$ A segunda alternativa, que parece mais provável a Herling, implicaria não um gesto válido de provocação artística, mas antes a paralisia de um credo indiferentista ou - pior - "a areia movediça do niilismo", * ambos os casos igualmente merecedores de peremptória reprovação.

A crítica grudzińskiana às narrativas de Borowski demanda ponderação (e longe está de pairar imune à controvérsia). Para nossos fins, todavia, basta que tenhamos aviso de seu raciocínio para efeito de melhor demarcação dos motivos e escolhas que determinaram o caráter artístico de Um outro mundo. Reitere-se, então: dar testemunho sobre o Gulag, nesta última obra, equivale a proferir julgamento pessoal categórico sobre os campos soviéticos. Um julgamento que, como foi mostrado, não se arroga sobrehumana clarividência nem dogma, e que deverá por isso ser tanto mais cioso do mister da prova. Necessitaríamos de grande vagar para uma análise circunstanciada do complexo aparato institucional do Gulag, tal como o vai revelando e acusando o livro de HerlingGrudziński. No afã de pôr abaixo a fachada inofensiva de normalidade com que se ocultam os reais propósitos e rotinas do campo de trabalho forçado comunista, o autor esquadrinha peça por peça - em chave sintética, bem entendido, mas com rigor e argúcia admiráveis - o vasto "sistema de crueldade organizada" entre cujas presas se encontrou. Sob esse aspecto, cabe com justiça equiparar o texto grudzińskiano, como o faz Włodzimierz Bolecki, a uma pequena encyklopedia łagrowa. Segundo o estudioso, o relato de Herling distinguiu-se por méritos cognitivos invulgares, trazendo à baila um sem-número "de achados sociológicos, econômicos, po-

\footnotetext{
${ }^{25}$ Herling-Grudziński resenhou em um texto de 1948 ("U kresu nocy") os contos de Tadeusz Borowski. Em seu livro, Bolecki detém-se atentamente na discussão da polêmica grudzińskiana em torno da ficção de Borowski.
} 
líticos e psicológicos que anos mais tarde foram ratificados por trabalhos acadêmicos e investigações especializadas [...]."*

Somos inteirados assim, ao longo da narrativa, das várias dimensóes da vida em um tagier na URSS: os tipos de prisioneiros e sua hierarquia, as instalações do campo, seu jargão, as modalidades e normas de trabalho, o cotidiano de medo, de exaustão, de fome e de doença dos detentos, sua torturada intimidade. Somos inteirados de que, sob a aparência de um empreendimento de estofo econômico e correcional, está em ação a hediondez do que se batizou, com rude expressividade, de um "moedor de carne" ${ }^{26} \mathrm{um}$ somatório de estruturas e expedientes repressivos (em sua maioria, a população dos campos compunha-se de presos políticos) cuja meta consistia, de fato, em precipitar a aniquilação física de suas vítimas, submetendo-as a jornadas laborais extenuantes (chegando não raro a dezesseis horas), sob clima inóspito, com equipamento e vestuário inadequados e dieta alimentar sadicamente insuficiente. Ante tal quadro, conclui-se logo que o ganho econômico, sendo sempre bem-vindo, não era de modo algum prioritário, e que a "correção" punitiva não passava de um eufemismo para acobertar o fito de completa desintegração da personalidade e da humanidade mesma do suposto inimigo do regime.

Da miríade de passos ilustrativos a nossa disposição nas páginas do livro, tomem-se apenas dois, na esperança de que permitam apreender - de um ângulo menos frontal que os estupros coletivos ou a coleta de alimento entre cascas de legumes e restos apodrecidos nas lixeiras - a extensão da violência instituída no Gulag. O fragmento transcrito abaixo pertence ao capítulo intitulado "Gritos noturnos":

Defoe descreve no Journal of the Plague Year pessoas evitando-se umas às outras por medo da peste. Fazíamos o mesmo, mas sem motivos tão evidentes. Seria quase possível acreditar, observando-nos à noite no barracão, que a morte é contagiosa. Temíamos seu contágio nos outros, portando já sob a pele, entretanto, seu embrião. Era tão-só um jogo de aparências, mas tão intenso e convincente que ao cair da noite cada prisioneiro se ocultava por um punhado de horas na dura carapaça do sono, como se nem com o mais delicado suspiro quisesse lembrar de sua existência a morte que espreitava no catre vizinho. Cada um de nós procedia de igual modo, mas cada um quiçá também pensava, com horror, que é um dos criadores e ao

\footnotetext{
${ }^{26}$ A expressão, segundo informa Anne Applebaum, foi cunhada pelos próprios reclusos (cf. Op. cit.: 3).
} 
* (HERLING-GRUDZIŃSKI, G. Inny świat: 228.) mesmo tempo uma das vítimas desse entendimento tácito de empesteados. E custa dizer se nos causava mais dor a ideia de que nunca nos tiraria do letargo da autoconservação o grito dos companheiros agonizantes, ou a consciência de que ninguém tampouco ouviria nosso chamado por socorro. Não me foi dado ver em vida, talvez, exemplo mais conspícuo de solidariedade no egoísmo. Jamais se falava em voz alta de tais assuntos, mas não havia prisioneiro ali que não se recordasse do momento em que assistiu, sem um tremor sequer e de pálpebras semicerradas, um cadáver sendo levado à noite para fora do barracão.*

No capítulo em que a longa citação foi recolhida, Herling descreve o concerto noturno de uivos e gemidos, de clamores e murmúrios a ressoar no barracão dos detentos. Em si mesma lancinante, a descrição da cena deixa-se todavia intercalar pela reflexão sobre o estado de permanente terror a que todos ali estão entregues, cônscios de que um único dia no campo custa anos inteiros de vida e, por conseguinte, a proximidade crescente da morte. Meditando sobre esse terror - vivido em comum, mas não compartilhado entre si pelos presos -, o narrador chama nossa atenção para o que mais consterna: a solidariedade no egoísmo, a atrofia do vínculo humano entre os reclusos. Uma vez rompido esse elo, quanto resta de humanidade em cada um deles?

A pergunta tem ainda mais razão de ser perante outro trecho da obra, o qual se lê no capítulo intitulado "Ressurreição". O narrador discorre nessa altura sobre o barracão em que funciona o hospital do campo, uma espécie de oásis de higiene, repouso e (relativa) abundância alimentar, um recinto à parte no tagier, cujo acesso não por acaso é cobiçado com veemência pelos prisioneiros, a ponto de desenvolverem com esse desiderato diversas práticas de automutilação. Sob um frio de trinta e cinco graus negativos, encharcado de suor por conta do esforço despendido no trabalho, Herling desnuda-se da cintura para cima e um dia depois jaz em um dos leitos hospitalares. Entre os luxos frugais das instalaçôes, consta o fato de que ali se apaga a luz à noite, o que devolve certa paz ao escritor e lhe proporciona algo como uma renascer da própria individualidade. Junto desse aprazível sentimento, porém, um outro se lhe depara:

Pois simultaneamente a essa euforia pela ressurreição da personalidade eu sentia ser o cemitério de tudo que me unia às outras pessoas. Eu não pensava no campo, não pensava naqueles que pereciam fora do bote salva-vidas do hospital, não pensava nos próximos, nos 
amigos, em ninguém - senão em mim mesmo. Eu morria, portanto, ressuscitando. Pensava com ódio cada dia maior no prisioneiro que amanhã chegaria para ocupar meu lugar. Esses instantes [...] devolveram-me a certeza de minha própria existência, privando-me do respeito pela existência dos outros. Eu era como um cego que, ao recobrar a visão, havia despertado em um vácuo repleto de espelhos que só refletiam sua própria solidão.*

De novo o relato surpreende - dessa vez no íntimo do narrador - uma progressiva corrosão da própria fibra do ser humano sob a sistemática violência imperante no campo. No exato momento em que acredita recobrar uma fração ao menos de sua subjetividade, o escritor descobre que nada traz em seu âmago, exceto o ácido do ódio e o deserto do que um dia foi um homem. Como ficou dito antes, os exemplos de violação e de degradação poderiam ser multiplicados. De nada mais precisamos, contudo, para que se aquilatem em sua devida ressonância as palavras de Gustaw Herling-Grudziński. Testemunhar sobre um campo soviético, como afirmou o autor, é

[...] descer os abismos de um inferno, até ali onde das profundezas das águas do Letes olham para mim as faces de companheiros mortos, e vivos ainda quiçá, retorcidas no esgar selvagem de feras acuadas, sibilando com os lábios arroxeados de fome e de sofrimento: diz toda a verdade sobre quem fomos, diz a que nos compeliram.*

Ao cabo desta rápida incursão por Um outro mundo, parece justificado subscrever a assertiva de que Herling procedeu à altura do repto com que se defrontou. Cabe no caso indagar, no entanto, se temos procedido de igual modo. ${ }^{27}$ Não faz muito tempo,

\footnotetext{
${ }^{27}$ Seria proveitoso trazer à baila, nesse passo, o problema da recepção da obra de Herling-Grudziński no quadro de polarização ideológica resultante da II Guerra e depois. À guisa de aceno ao assunto - que demandaria vagar -, aluda-se tão-só aos infortúnios de Um outro mundo na França, bastante reveladores no que tange à atitude da inteligentsia ocidental de esquerda na época. Segundo anota Tzvetan Todorov (Face à l'extrême; nouvelle édition. Paris: Seuil, 1994: 163), o livro "será recusado por todos os editores franceses, e notadamente pela Gallimard, malgrado as insistentes intervenções de Albert Camus, uma das raras personalidades do mundo literário a denunciar os campos soviéticos - o que lhe vale sólidas inimizades; tudo o que concerne à União Soviética, força é verificá-lo, é submetido à censura." Assim, apesar de entendimentos travados já em 1952 com a editora Plon, a versão francesa da obra grudzińskiana só virá a lume em 1985, pela Denoël, graças à intervenção do escritor espanhol Jorge Semprun. No estudo a que repetidas vezes já recorremos aqui, Włodzimierz Bolecki discute em pormenor os destinos da obra a partir de seu lançamento na Inglaterra em 1951. Cf. Op. cit.: 72-83 et passim.
}

* (Ibidem: 166 167.) 
* (HOBSBAWM, Eric. Era dos extremos. O breve século XX: 1914-1991; trad. Marcos Santarrita; $2^{a}$ ed., $28^{\mathrm{a}}$ reimp. São Paulo: Cia. das Letras, 2004: 13.)

* (HARTMAN, Geoffrey. "Public Memory and Its Discontents". In: HARTMAN, G. \& O'HARA, Daniel T. (Ed.). The Geoffrey Hartman Reader. New York: Fordham University Press, 2004: 415.)

* (Ibidem.)

* (Ibidem.)
Eric Hobsbawm verificou, em sua Era dos extremos, que "a destruição do passado - ou melhor, dos mecanismos sociais que vinculam nossa experiência pessoal à das gerações passadas - é um dos fenômenos mais característicos e lúgubres do final do século XX.”* Tornando ainda mais complicado o impasse, conforme argumenta Geoffrey Hartman, impõe-se a questão da "própria eficiência dos meios de comunicação modernos", de "seu realismo" e largo "escopo representacional", ${ }^{*}$ os quais acarretam, em resultado da velocidade e da quantidade do que nos impingem, uma síndrome da informação, um mal-estar da memória pública, bem como da memória individual:

Entre os sintomas dessa moléstia de nossa época estão discussōes filosóficas sobre a existência ou inexistência de um "sujeito póshumano", uma conferência acerca d'“Os Usos do Oblívio", e o temor, francamente expresso, de que "nosso passado não tenha futuro em nosso futuro" (David Rieff). Mesmo com o rotineiro assédio a nossos sentidos, a imaginação, tradicionalmente definida como um poder que restitui certo tipo de presença a coisas ausentes, tem seu mister alijado e está em perigo de imitar o sensacionalismo da mídia. Ela se torna, como disse Wallace Stevens, uma violência de dentro investindo contra a violência de fora.*

Indaga em vista disso o teórico da literatura norte-americano: "Como manter viva nossa sensibilidade, quando eventos tão vívidos e pungentes se tornam nosso pão de todo dia? Como impedir que a recusa e a indiferença prevaleçam?”* A hipótese aventada por Hartman é de que as artes, e em especial a literatura, têm um papel crucial desse ponto de vista, quer como agentes do cultivo e da ininterrupta reatualização dos legados da memória, quer como adversárias do fenômeno contemporâneo da "produção da indiferença moral" ${ }^{28}$ No mesmo diapasão de pensamento, arrisquemos de nossa parte a hipótese de que o processo que Hobsbawm indigita possa ser revertido. Se não estivermos errados, obras como a de Herling-Grudziński serão um bom lembrete de que temos pela frente passados a construir. Vale dizer - futuros de outro presente.

${ }^{28}$ Esta última fórmula, como se sabe, é da autoria de Zygmunt Bauman, em seu Modernity and the Holocaust (Ithaca: Cornell University Press, 1989). Apud HARTMAN, op. cit.: 416. 
Marcelo Paiva de Souza é doutor em Ciência da Literatura (Uniwersytet Jagielloński, 2000), professor de Teoria da Literatura, Teoria da Tradução e Literatura Polonesa na Universidade Federal do Paraná, e tradutor. Publicou, entre outros, Teatr niepokoju. Studium porównawcze dramaturgii Stanisława Ignacego Witkiewicza i Oswalda de Andrade (2001), Czestaw Mitosz: não mais (antologia poética em parceria com Henryk Siewierski; 2003), Jacopone da Todi: flagelo e amor (antologia poética; 2006). Traduziu, entre outros títulos, os romances A viagem, de Ida Fink (1998), Branco neve, vermelho Ruissia (2007), de Dorota Masłowska, e, mais recentemente, as Meditaçôes Sul-Americanas (2009), de Hermann Keyserling. (mrclpvdsz@hotmail.com)

\section{Resumo}

O artigo tem por objetivo apresentar aos leitores brasileiros e hispano-americanos uma testemunha exemplar do Gulag, o escritor polonês Gustaw Herling-Grudziński (1919-2000), e sua obra Inny świat/Um outro mundo (1953), relato pungente sobre a vida nos campos soviéticos e lúcida análise do terror político instaurado pelo sistema repressivo do regime comunista. Levando em conta os debates acerca do totalitarismo, bem como os estudos que hoje são consagrados à literatura testemunhal (particularmente na América Latina e na Polônia), propóe-se uma leitura de Um outro mundo. Que questóes o texto grudzińskiano suscita em tal contexto?

\section{Abstract}

This article aims at introducing to the Latin-American readers an exemplary witness of the Gulag, the Polish writer Gustaw Herling-Grudziński, and his work $A$ World Apart, a poignant account of life in the soviet camps, and at the same time a lucid analysis of the political terror established by the communist regime's repressive system. A reading of $A$ World Apart is proposed, in view of the discussions about the concept of

\section{Résumé}

Cet article a pour but de présenter aux lecteurs brésiliens et hispano-américains un témoin exemplaire du Goulag, l'écrivain polonais Gustaw Herling-Grudziński, et son ouvrage Un monde à part, à la fois poignant récit de la vie dans les camps soviétiques et lucide analyse de la terreur politique instaurée par le système répressif du régime communiste. En tenant compte des débats sur le totalitarisme ainsi que des étu-
Palavras-chave: Gulag; testemunho; literatura polonesa do século XX; Um outro mundo, de Gustaw HerlingGrudziński.
Keywords: Gulag; testimony; twentieth-century Polish Literature; Gustaw Herling-Grudziński's $A$ World Apart.

Mots-clés: Goulag; témoignage; littérature polonaise du XXème siécle; Un monde à part de Gustaw HerlingGrudziński. 
totalitarianism, as well as the des qui aujourd'hui sont consacontemporary research on tes- crées à la littérature testimoniale timony in literature (particu- (particulièrement en Amérique larly in Latin America and Po- latine et en Pologne), on proland). Which issues are raised pose ici de lire Un monde à part. by Herling-Grudziński's text in Quelles questions suscite le texte that context? de Herling-Grudziński dans un tel contexte? 